\title{
5-HT2 and 5-HT2B inhibitors mitigate fibrotic phenotype of peritoneal fibroblasts via non-canonical signaling in patients on continuous ambulatory peritoneal dialysis
}

\author{
Saurabh Chaturvedi ${ }^{1}$, Harshit Singh ${ }^{1}$, Ravi Mishra ${ }^{1}$, Vikas Agarwal ${ }^{1}$, K C Rastogi $^{2}$, Narayan Prasad $^{3}$ \\ ${ }^{I}$ Clinical Immunology, Sanjay Gandhi Post Graduate Institute of Medical Sciences, India, ${ }^{2}$ Hygia Institute of \\ Pharmaceutical Education and Research, India, ${ }^{3}$ Nephrology, Sanjay Gandhi post graduate Institute of Medical \\ Sciences, India
}

\section{Background}

Peritoneal fibrosis is a major cause of ultrafiltration failure in continuous ambulatory peritoneal dialysis (CAPD) patients . 5-hydroxytryptamine (5-HT) induces extracellular matrix synthesis in peritoneal fibroblasts in Transforming growth factor beta 1 (TGF $\beta 1$ ) dependent manner. We aimed to evaluate antifibrotic role of 5-HT2 and 5-HT2B inhibitors Terguride and SB 204741 respectively in human peritoneal fibroblasts (HPFB) isolated from omentum and parietal peritoneum of CAPD patients.

Methods

Omentum biopsy $(O B)$ of control patients $(n=6)$ undergone elective abdominal surgery and CAPD patients $(n=4)$ was washed with sterile PBS and incubated in $0.125 \%$ trypsin/0.01\% EDTA twice for 20 minutes followed by two times for 40 minutes at $37^{\circ} \mathrm{C}$. Biopsy from parietal peritoneum PB excised during laparotomy incubated overnight in dispase (2.4 $\mathrm{U} / \mathrm{mL}) / 37^{\circ} \mathrm{C}$. After centrifugation pellet obtained from $\mathrm{OB}$ and $\mathrm{PB}$ incubated in complete DMEM gave HPFB within 2 weeks - In first strategy HPFB from OB and PB were incubated with (5-HT-1 $1 \mu \mathrm{M})$ for $1 \mathrm{hr}$ and later with $(5-\mathrm{HT}-1 \mu \mathrm{M})$ and (Terguride, SB 204741-1 $\mathrm{MM}$ each) for $24 \mathrm{hr}$. In second strategy HPFB from OB and PB were pre-treated with (Terguride, SB 204741-1 $\mathrm{MM}$ each) for $1 \mathrm{hr}$ and later with only $(5-\mathrm{HT}-1 \mu \mathrm{M})$ for $24 \mathrm{hr} \cdot$ Real time qPCR for pro-fibrotic (TGF $\beta 1$, Col1a1, Col1a2, ACTA2, CTGF and FN1) and anti-fibrotic genes (MMP2/TIMP1) expression was performed - Type I collagen and $\alpha$ SMA phosphorylation status of Smad3 and ERK1/2 was examined by immunoblotting. Results

In 5-HT stimulated HPFB upregulated expression of profibrotic genes $(\mathrm{p}<0.05)$ mRNA at $24 \mathrm{hr}$ was observed $\cdot$ Coculture of HPFB with 5-HT2 and 5-HT2B receptor antagonists Terguride and SB 204741 significantly reduced profibrotic genes expression $(\mathrm{p}<0.05)$ in both the strategies. Effect on anti-fibrotic genes mRNA in both the strategies was not affected. Pre-treatment with Terguride and SB 204741 decreased the production of type 1 collagen and $\alpha$ SMA significantly $(\mathrm{p}<0.05) \cdot 5$-HT dose dependently increased the mRNA levels of TGF $\beta 1$. Terguride and SB 204741did not influence Smad3 phosphorylation (canonical pathway) rather they significantly reduced ERK1/2 phosphorylation (noncanonical pathway) $\mathrm{p}<0.05$.

Conclusion

5-HT2 and 5-HT2B receptor antagonists reduce profibrotic mRNA expression in 5-HT stimulated HPFB by suppressing TGF $\beta 1$ mediated noncanonical pathway. 